\title{
COVID-19 and pregnant women - An overview on diagnosis, treatment approach with limitation, and clinical management
}

\author{
Laxmi Pattanashetti ${ }^{1}$, Santosh B. Patil ${ }^{1}$, Sanath Nyamgouda ${ }^{2}$, Mahendra kumar R Bhagiratha ${ }^{2}$, \\ Pramod C. Gadad ${ }^{1}$ \\ ${ }^{1}$ Department of Pharmacology; ${ }^{2}$ Department of Pharmacy Practice, KLE College of Pharmacy, Hubli (A constituent \\ unit of KLE Academy of Higher Education and Research, Belagavi), Karnataka, India
}

\begin{abstract}
Coronavirus disease or more popularly called COVID-19 is known to be caused by a novel coronavirus 2 . The COVID-19 has been identified to be originated from Wuhan, Hubei, China. This pandemic started in December 2019, and since then it has spread across the world within a short period. The health and family welfare ministry of the Government of India reported 227,546 active, 9,997,272 discharged cases, and 150,114 deaths due to COVID-19 as of 06 January 2021. Indian Council of Medical Research
\end{abstract}

Correspondence: Laxmi Pattanashetti, Assistant Professor, Department of Pharmacology, KLE College of Pharmacy, Hubli (A constituent unit of KLE Academy of Higher Education and Research, Belagavi), Karnataka, India.

Tel. +91.8217496180. E-mail: pattanashetti.laxmi67@gmail.com

Key words: COVID-19; pregnant women; pathogenesis; management

Ethics approval and consent to participate: Not applicable.

Availability of data and Material: Accessible.

Conflict of interest: The authors declare that they have no competing interests, and all authors confirm accuracy.

Contributions: LP, participated in study concept, manuscript drafting, data collection; SBP, contributed in data collection, manuscript drafting; $\mathrm{SN}$, was involved in data validation, manuscript review; MRB data collection; PCG, contributed to manuscript review and finalization. All the authors have read and approved the final version of the manuscript and agreed to be accountable for all aspects of the work.

Acknowledgments: All the authors are thankful to The Principal, KLE College of Pharmacy, Hubli (A constituent unit of KLE Academy of Higher Education and Research, Belagavi- Karnataka) India for encouraging and providing necessary support.

Received for publication: 28 January 2021.

Accepted for publication: 15 April 2021.

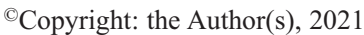

Licensee PAGEPress, Italy

Monaldi Archives for Chest Disease 2021; $91: 1785$

doi: 10.4081/monaldi.2021.1785

This article is distributed under the terms of the Creative Commons Attribution Noncommercial License (by-nc 4.0) which permits any noncommercial use, distribution, and reproduction in any medium, provided the original author(s) and source are credited.
(ICMR) reports that the cumulative testing status of SARS-CoV-2 (COVID-19) was 931,408 up to November 03, 2020. Currently, no specific anti-viral drug for COVID-19 management is recommended in the current scenario. Vulnerable populations such as pregnant women affected by COVID-19 infection need to be recognized and followed up for effective handling concerning morbidity and mortality. At present, very few case reports on COVID19 infected pregnant women have been published in India and there is no proven exclusive treatment protocol. This article summarizes a review of signs and symptoms, etiopathogenesis, risk factors, diagnosis, and possible management of COVID-19 infection in pregnant women. This overview may be useful for health care providers for practical approach and limitation of drugs used in the current management and considers the choice of drugs with their special attention given to adverse effects to improvise maternal health, pregnancy, and birth outcomes.

\section{Introduction}

Coronavirus disease or more popularly called COVID-19 is known to be caused by novel coronavirus 2 and it is presented with the specific syndrome with extreme acute respiratory distress being the most prominent feature. In general, initial infection is presented with mild to severe respiratory symptoms and gradually can lead to respiratory failure) later can be life- threatening due to multi-organ failure. The COVID-19 has been identified from Wuhan, Hubei, China. This pandemic started in December 2019, and since then it has spread across the world within a short period [1].

India currently has the highest number of confirmed cases of COVID-19 infection in Asia and the third-highest number worldwide [2]. The World Health Organization has discussed the global effects of the epidemiological situation, with over 32.7 million COVID-19 cases and 991,000 deaths recorded by the end of September 2020; total deaths are predicted to surpass one million in the future. South-East Asia is the second most affected region, accounting for $21 \%$ and $11 \%$ of total cases and deaths, respectively. It has been recorded that countries such as India, Indonesia, and Bangladesh continue with the greatest numbers [3].

Indian Government launched the mobile application named AarogyaSetu, which was developed to reach the app users about the best practices, risks, and relevant advisories related to COVID-19 containment. ArogyaSetu app data indicate about 10,374,932 confirmed cases, 9,997,272 recovered and 150,114 deaths were reported as of January 06, 2021. Totally 167.6 million users of the AarogyaSetu mobile application helped to update the country's health status [4]. According to the ministry of health and family wel- 
fare of Government of India reported 227,546 active COVID-19 cases, 9,997,272 discharged and 150,114 deaths till 06 January 2021. Indian council of medical research reports that the total Testing Status of SARS-CoV-2 was 9,31,408 which were cumulative total samples tested up to November 03, 2020 [5]. There is no specific anti-viral drug for COVID-19 outbreak management in the current scenario [6]. The elderly ( $>65$ years) persons, people with the impaired immune system, and perhaps pregnant women have been reported to be susceptible to the virus [7-9].

As per earlier reports, women are categorized vulnerable to respiratory infections, especially during pregnancy. However, pregnant co-morbidity patients may have an increased risk of serious illness, consistent with the general population of similar co-morbidity patients. High-risk groups need to be monitored accordingly by clinicians. Around $85 \%$ of women will experience mild illness, $10 \%$ more severe illness, and 5\% more critical illness [10]. At present, very few case reports on COVID-19 pregnant women have been published in India and there is no proven exclusive treatment protocol for its management. Vulnerable populations such as pregnant women affected by COVID-19 infection are very important to recognize and follow-up and the cases should be handled effectively concerning morbidity and mortality.

However, in India, a protocol for the management of pregnant women affected by COVID-19 has been prepared by the Indian Council of Medical Research. Yet the normal protocol and procedure need the hour to learn and adapt. Here we summarize a review of signs and symptoms, etiopathogenesis, risk factors, diagnosis, and possible management of pregnant women infected with COVID-19.

\section{Signs and symptoms}

Fever, dyspnea, cough, lymphopenia are predominant features of COVID-19 in pregnancy, similar to non-pregnant patients. $18 \%$ of patients reported breath shortness. In some cases, due to increased maternal oxygen requirements from increased metabolism, gestational anemia, and fetal oxygen consumption, which are common in pregnancy, this may be difficult to discern from physiological dyspnea [11]. Initially in China reports specified seven COVID-19 affected pregnant women showed symptoms viz. cough, fever, diarrhea, and shortness of breath [12]. As described above, the symptoms can differ, and women with a variety of clinical manifestations ranging from mild symptoms and signs to serious disease, including pneumonia with or without acute respiratory distress syndrome (ARDS), renal failure, and multi-organ dysfunction can require immediate to advanced critical care support. As a consequence, those affected are generally described as having moderate, serious, or critical illness [13]. In one of the studies critically ill pregnant women affected by COVID-19 needed oxygen were reported to have cardiomyopathy [14]. To evident such cases, more data is required to require optimizing incidence of the incidence of cardiomyopathy secondary to postnatal or in pregnant COVID patients.

There are signs of very high fever associated with coughing, trouble breathing, diarrhea, pneumonia, headache, excess sputum, and hemoptysis in infected people with symptoms. Some people with infections are asymptomatic and, since they ignore health conditions, are labeled as highly infectious. Conditions such as respiratory arrest, heart attack, RNA anemia, and ground-glass opacity were fatal events [15-17].

\section{Etiology}

SARS-CoV-2 of order Nidovirales, belonging to the family Coronaviridae is causative of Coronavirus disease-19. These are non-segmented, enveloped RNA viruses that include the coronaviruses of SARS-CoV and MERS-CoV [18].

Vulnerable groups are susceptible to COVID-19 especially pregnant women/lactating mothers. Current knowledge and clinical management of pregnant women with COVID-19 is mainly based on information from the general population. In spite of the growing number of pregnant women with COVID-19, data on the clinical characteristics and disease severity of pregnant patients are still limited. Considering the particularity of immune status and physiological features in pregnant women, there is an urgent need to investigate the differences in the clinical characteristics and severity of COVID-19 between pregnant and nonpregnant women and the potential impact of COVID-19 infection on the clinical outcomes of the fetus and neonate [19].

\section{Pathogenesis of COVID-19}

COVID-19 contains a single-stranded RNA genome with 4 genes: nucleocapsid, membrane, envelope, and spike protein [20]. The pulmonary area is the main target of the virus. Coronavirus binds via receptor-binding domains to the host receptor, named ACE2 [21]. For the release of RNA in a host cell, conformational changes occur by spike protein which activates the viral envelope to bind with a receptor of a hostcell. Viral replication happens when RNA enters the host cell later proteinases enzymes dividing them into small particles. Later translated using mRNA's and stored in the endoplasmic reticulum and Golgi apparatus through which they are released as vesicles into endothelial, alveoli, and blood cells [22].

\section{Role of lymphocytes in COVID-19}

The immune system plays an important role to fight against viruses and other microorganisms. Especially lymphocytes ( $\mathrm{T}$ and B cells), natural killer cells are essential [23]. Compared with non-pregnant women, the total white cell count was significantly increased at all pregnancies and also post-partum. In pregnancy the absolute number and percentage of $\mathrm{T}$ lymphocytes was slightly elevated while almost no changes in B cells were found. No significant changes were found in the percentage of suppressor/cytotoxic (CD8+), of helper/inducer (CD4+) T lymphocytes, nor of CD4+/CD8+ ratio at any stage of pregnancy and puerperium [24]. However pregnant COVID-19 patients showed significantly lower numbers of blood lymphocytes and higher numbers of neutrophils, as well as higher levels of C-reactive protein and total bilirubin.

Signature features of COVID-19-related severe illness include the presence of elevated levels of pro-inflammatory cytokines, coagulopathy, and lymphopenia. However, no deaths were reported, dissociating lymphopenia in the patients from mortality. Thus, the question of whether pregnancy is an immunological contributor to severe or controlled COVID-19 disease should be extensively debated [25]. 


\section{Role of D-DIMER and thromboembolism}

It is assumed that the mechanism by which COVID-19 infection causes multi-organ dysfunction involves inflammatory cytokines release which triggers tissue factor development and activates thrombin. Increased thrombin and D-dimer $(>1 \mu \mathrm{g} / \mathrm{mL})$ are linked with an increased risk of death.

It was presumed COVID-19 affected pregnant women less likely to have serious morbidity/die, however, reports indicate a subset can develop multi-organ failure that leads to death. During common infections generally, pregnant women show evidence of elevated intravascular inflammation and increased thrombin along with prothrombin which might exaggerate thrombosis risk [26].

\section{The inflammatory response in COVID-19}

COVID-19 patients are in extreme need of intensive care as per previous reports since different inflammatory mediators are involved to provoke response [8,9]. In another study, IL-6 numbers appear to increase with time in COVID-19 patients and are comparatively higher in non- survivors than in survivors [27]. Critical patients addressed substantially higher percentage of peripheral blood inflammatory monocytes in CD14+CD16 + compared to patients with moderately ill [28].

Cytokine storm is contributed by the release of cytokine along with IP-10, MCP, and MIP1 alpha. The cytokine storm also has body-wide ripple effects. Elevated levels of TNF with cytokines can result in circulatory failure and myocardial damage led by sep- tic shock $[29,30]$. During viral infection, the inflammatory process is associated with high plasma levels of cytokines, as cytokines storm, including IL-2, IL-7, IL-10, G-CSF, IP-10, MCP-1, MIP$1 \mathrm{~A}$, and TNF $\alpha$. This might play an important role in pregnancy as IL-2 has been implicated to be upregulated in pre-eclampsia, miscarriage and IL-7/IL-7R signaling pathway in fetal miscarriage, due to the upregulation in the ratio of Th17/Treg cells.

Another relevant aspect is the possible implication of polymorphisms in COVID-19 diseases, as is well-documented for other viral infections. Also, cytokines polymorphisms, such as TNF- $\alpha$ 308G/A (rs1800629) polymorphism is associated with recurrent miscarriage. In fact, TNF- $\alpha$ and TNF- $\alpha$ receptor play an important role in the development of the fetus, being present in the ovary, endometrium, placenta, and fetus, and in the amniotic fluid in different concentration. This increase in TNF- $\alpha$ during pregnancy may implicate in different health outcomes depending on the gestational period, leading to tissue necrosis in the placenta and hypoxia [31].

\section{Role of $A C E 2$ receptor in the pathogenesis of COVID-19 infection in pregnant women}

Mechanism of vascular injury up-regulation of the ACE 2 receptor during pregnancy can increase the risk of coronavirus 2 infections with the severe acute respiratory syndrome. ACE 2 virus affinity contributes to decreased regulation and may increase Angiotensin II levels compared to Angiotensin(1-7), which favors vasoconstriction and may exacerbate vascular dysfunction in preeclampsia cases as shown in Figure 1.

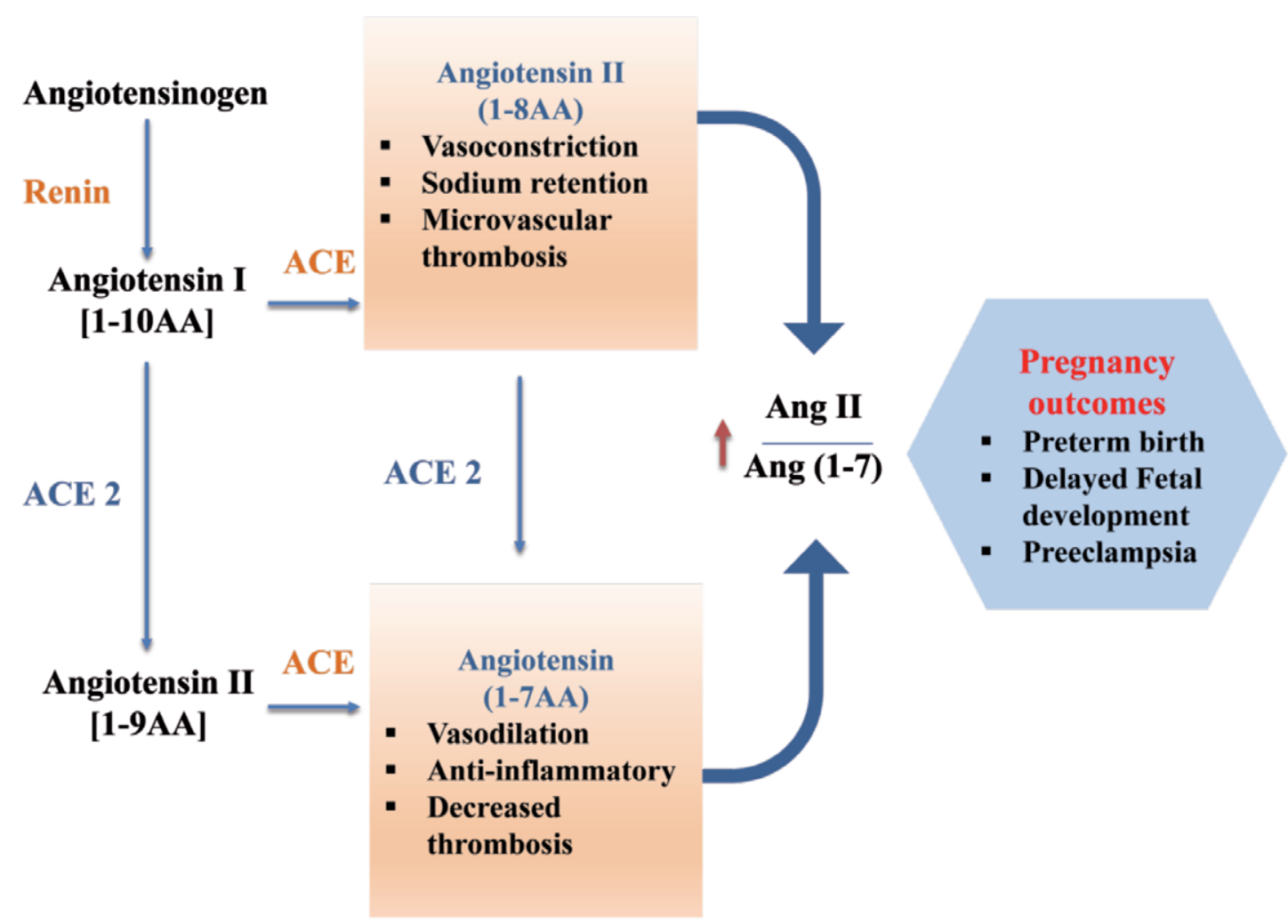

Figure 1. Role of angiotensin in pregnant women. 
ACE2 converts angiotensin (Ang) II to Ang-(1-7), and Ang I to Ang-(1-9), then back to Ang-(1-7), allowing blood pressure to be controlled. ACE2 in syncytiotrophoblasts is believed to help vasodilate the maternal vasculature by regulating the release of Ang 1-7 into the bloodstream [32]. The placentas, uterus, and kidneys were all found to be significant sources of ACE2 activity in one analysis, bolstering the theory that transient ACE2 over expression and increased activity throughout pregnancy may modulate hemodynamics within the uteroplacental structure [33].

During gestation, ACE2 and Ang-(1-7) can serve as autocrine/paracrine regulators for early pregnancy angiogenesis, apoptosis, and development, as well as late pregnancy uteroplacental blood flow events, with late pregnancy models demonstrating augmented ACE2 and decreased uterine perfusion pressure models illustrating substantial ACE2 depletion [34]. The ACE2 receptor is demonstrated predominantly during the first months of pregnancy by placental syncytiotrophoblast cells. Early ACE2 expression, which has been linked to placental immaturity, makes the first trimester the most possible time for SARS-CoV-2 infection [32]. For viral entry, a serine protease called TMPRSS2 is also necessary [35,36], and placental expression is still a topic of debate. mRNA expression in human placentas is reported to be low [37] but present in some studies, while it is not reported in others [38]. Because TMPRSS2 and ACE2 expression are linked in the first few months of pregnancy, this period is more vulnerable to SARS-CoV-2 infection. Li et al. confirmed this high level of ACE2 expression in maternal- fetal interface cells, such as decidua stromal cells and perivascular cells, as well as placental cytotrophoblast and syncytiotrophoblast [38]. In comparison, a recent study showed that in the third trimester, co-transcription of ACE2 and TMPRSS2 (transmembrane proteases) in the placenta was marginal, and chorioamniotic membranes lacked expression of SARS-CoV-2 receptors, implying that the placenta was an unexpected pathway for vertical transmission [39]. However, the authors did not rule out the possibility that SARS-CoV-2 could infect the placenta by a different route and via interactions with other proteins, such as Basigin (also known as CD147 or EMMPRIN), a transmembrane glycoprotein that belongs to the immunoglobulin superfamily and is highly expressed in the placenta and chorioamniotic membranes [40]. Dexamethasone-induced reductions in placental expression of ACE2 and Ang-(1-7) have been related to intrauterine growth restriction and possibly disease programming in adulthood [41]. During the normal gestation period, there is an increase in ACE2 enzyme is Renin- Angiotensin-Aldosterone System this could be a risk factor for COVID infection in pregnant women [42]. Furthermore, hypotensive pregnant women sustained by the refractory response of Angiotensin II results in vasodilatation systemically $[43,44]$. Around $3.5 \%$ of pregnancies are associated with preeclampsia due to a gestational hypertensive state [45]. Clinically, multisystem involvement and, typically, proteinuria are characterized; this equilibrium is lost, with an exaggerated reaction to blood pressure from Ang II. Decreased maternal plasma Ang- (1-7) levels have also been associated with Preeclampsia [44]. Since not only does SARS-CoV- 2 bind to ACE2, it also induces its downregulation, COVID infection during pregnancy may potentiate the RAAS abnormalities, , dysregulation of ACE2, including coagulation abnormalities endothelial cell dysfunction (immune cell-mediated) was also identified recently $[46,47]$.

\section{Pregnancy registries}

To gather data on how COVID-19 affects pregnancy and newborns, registries are being created through different international officials [48].

\section{Prevalence of congenital infection}

In several cases of third-trimester maternal infection within 14 days of delivery, the possible vertical transmission was identified, indicating congenital infection is possible but rare $(<3$ to $4 \%$ of maternal infections). It is assumed that most neonatal infections arise from respiratory droplets they are exposed to mothers/caregivers after delivery [49-51].

\section{The risk for congenital infection}

One downside to the diagnosis of maternal-fetal transmission is that the acceptance criteria are not fulfilled by conclusive proof of congenital infection. We agree, in general, with the criteria proposed by Shah et al. maternal symptoms and epidemiological exposure, maternal test outcomes, neonatal clinical status at birth, and neonatal test results are taken into account in the system [52].

Intrauterine fetal death/stillbirth congenital infection: Diagnosed by fetal or placental tissue polymerase chain reaction (RT-PCR) or electron microscopy to detect viral particles in tissue or culture to detect viral development in fetal or placental tissue. RT-PCR virus identification from the fetal surface or the fetal side of the placenta will be identified as a potential infection. If the virus was only identified by RT-PCR from the maternal side of the placenta in a surface swab and RT-PCR and no virus detection from fetal or placental tissue was carried out, then it is unlikely to consider that there is infection.

Congenital infection in live babies: depends on the presence or absence of clinical features of SARS-CoV-2 infection in newborns and mothers. Congenital infection is confirmed in symptomatic cases if the virus is detected byRT-PCR in umbilical cord blood or neonatal blood collected within the first 12 hours of birth or amniotic fluid collected before membrane rupture. Neonatal infection is confirmed in asymptomatic cases if the RT-PCR virus is detected in cord blood or neonatal blood collected within 12 hours of birth. There are also criteria for likely, possible, unlikely, or noninfectious.

Neonatal infection may be acquired intrapartum: intrapartum infection is reported for symptomatic newborns of infected mothers if the SARS-CoV-2 RT-PCR of the nasopharyngeal swab is both positive at birth (after cleaning the infant) and at 24 to 48 hours of age, and an alternative cause of the symptoms is excluded. There are also requirements for probable, possible, impossible, or noninfectious.

Neonatal infection may be acquired postpartum: This is established by the clinical characteristics of COVID-19 at about 48 hours of age (regardless of parent/caregiver SARS- CoV-2) 
and verified if the respiratory sample SARS-CoV-2 RT-PCR at birth is negative, but the nasopharyngeal/rectal swab SARS-CoV2 RT-PCR is positive at 24 to 48 hours of age [52].

\section{Diagnosis}

The current gold standard to detect COVID-19 infections/ suspected specimens by Real-time reverse transcriptase Polymerase Chain Reaction with $70 \%$ specificity [53]. Chest imaging and re-testing helps confirm infection if initially, negative swab persists even if clinically has symptoms. In the early stages of pregnancy, the peripheral count of WBC's/lymphocytes are reduced C-reactive protein may be increased. There may be mild thrombocytopenia, elevated liver enzyme levels, and creatine phosphokinase in some patients.

Without contrast, computed tomography (CT) scan of the chest is most essential to confirm pneumonia or to rule out pneumonia as it avoids radiation exposure to the fetus. Compared to the RT-RT-PCR test, chest CT revealed greater diagnosis (71\% vs $98 \%$ respectively) as per the recent study. In the vast majority of recorded COVID-19 infection pregnancies, radiological symptoms of viral pneumonia were present [54].

Given its high specificity for COVID-19, RT-PCR testing can be used as an independent diagnostic tool; however, some studies say it has limited sensitivity. While COVID-19 chest CT sensitivities vary by sample, many of these recorded sensitivities are higher than those for RT-PCR research. Many trials, however, have exaggerated CT's vulnerability and used approaches that are fraught with confounding factors and skewed patient populations $[55,56]$. In a study by Bai et al. concluded that the sensitivity of chest CT was greater than that of RT- PCR in COVID-19 subjects and endorsed the use of chest CT to test for COVID-19 infection that have clinical and epidemiologic features that are consistent with COVID-19 infection, particularly when RT-PCR findings are negative [57]. On the other hand, in a meta-analysis covering the broad prevalence range,RT-PCR sensitivity was reported to be $94 \%$ and specificity of $37 \%$ [58], which is contrary to the study done by Fang et al. [59]. The sensitivity and specificity of RT-PCR and chest CT for COVID-19, as seen in the literature are controversial and the subject matter for the debate. However, CT scans alone are unable to diagnose viral pneumonia and have a lower sensitivity than RT-PCR. COVID-19 scanning was found to be more sensitive when RT-PCR and CT scan were used were used in combination $[60,61]$.

Specimens should be collected, by saliva, the swabs through oropharyngeal and nasopharyngeal, or sputum urine and fecal matter. For confirmation of the diagnosis, repeated testing may be needed.

Suppose the SARS-COV-2 nucleic acid is not observed in samples taken at least 24 hours apart on two consecutive occasions, it is possible to rule out COVID-19. If RT-RT-PCR is not available serology is used as a diagnostic tool. Before starting antimicrobial therapy, blood cultures that ideally causes pneumo$\mathrm{nia} / \mathrm{sepsis}$ is essential to be considered [62]

Some laboratory abnormalities associated with COVID-19 in pregnant women, such as thrombocytopenia, elevated liver enzyme levels, and hemolysis, are typical characteristics caused by extreme preeclampsia and HELLP syndrome. In COVID-19, prolonged prothrombin time; elevated levels of D-dimer, procalcitonin, and C-reactive protein (CRP); and low levels of fibrinogen can also be observed (note that the reference ranges for D- dimer, CRP, and fibrinogen levels in pregnant women are higher $[63,64]$.

Neurological symptoms of COVID-19, as well as results of preeclampsia with extreme features/eclampsia, can be headaches, acute cerebrovascular disorder, and seizures. In COVID-19 and as a complication of obstetric disorders, acute kidney injury can occur ( preeclampsia with extreme features, abruptio placentae, shock). Such diagnoses should also be considered and COVID19 can coexist with them [65-67].

\section{Testing strategies in India}

Newborns are at risk of COVID-19 infection by asymptomatic pregnant women In this regard, the ICMR proposed on $20^{\text {th }}$ April 2020 that SARS-CoV-2 be screened in all pregnant women living in clusters/containment areas or large migration meetings/evacuation centers from hotspot districts in India and functioning or likely to be delivered in 5 days. Which greatly increased the rate of testing and also the number of obstetric patient referrals with confirmed COVID-19.

ICMR recommends testing of reported cases for only symptomatic patients (symptoms of influenza-like disease) and asymptomatic immediate or high-risk contacts in its recent strategy. It also endorses that emergency procedures, such as delivery, should not be delayed due to a lack of testing and that the same criteria should be adapted when sending samples for testing. The inpatient research approach was also revised accordingly where all patients were initially sent oropharyngeal swabs for (RT-RTPCR) every 48 hours, this modified to send them only on a caseby-case basis when repeat swabs were sent before discharging them from the hospital for critically ill or immune-compromised patients. Sampling, packaging, and transport of all specimens collected to comply with the MoHFW guidelines [68].

As per respiratory infection severity, admission criteria are chosen for pregnant women depends on mild or moderate/severe signs. In Table 1, the admission criteria are used in detail. The modified severity scale of the CURB (Confusion, Urea, Respiratory rate, Blood pressure) will help us determine the severity and standardized guidelines can assess the need for critical treatment (adapted from the American Thoracic Society and Infectious Diseases Society of America) as shown in Table 2 [69].

\section{Management of pregnant women with COVID-19}

There are several challenges in the management of COVID-19 infected pregnant women starting from screening, during labor and delivery along with protection of the healthcare unit [70]. The clinical management of pregnant women is shown in the Figure 2.

\section{Treatment approaches with limitation of drug therapies}

The list of drugs used in the management of COVID-19 infection in pregnancy is shown in Table 3. 


\section{Plasma therapy}

In addition to drugs such as Remdesivir, Lopinavir / Ritonavir, steroids, convalescent plasma has been used effectively in a few pregnant women; it should be conducted as part of a clinical trial, if possible, which will assess protection and efficacy. Two studies have conducted the impact of plasma in COVID-19 patients at the University of Pennsylvania in the United States and are available to pregnant women who meet inclusion criteria [71,72].

\section{Micronutrients}

Micronutrients especially vitamin B12, Zinc, and serum $25(\mathrm{OH}) \mathrm{D}$ play important role in pregnant women. Yalcin et al.

Table 1. Admission criteria for pregnant women during COVID-19 pandemic. Adapted from López M, Gonce A, Meler E, et al. C. Fetal Diagn Ther 2020;47:519-28; with permission [69].

\begin{tabular}{|c|c|c|}
\hline \multirow[t]{2}{*}{ Hospital } & \multicolumn{2}{|r|}{ Intensive care unit } \\
\hline & Major criteria & Minor criteria \\
\hline $\begin{array}{l}\text { - If there is persistent fever more than } 38^{\circ} \mathrm{C} \text { even after treating } \\
\text { with paracetamol } \\
\text { - } \quad \text { Chest X-ray demonstrating pneumonia } \\
\text { Pregnant women with co morbidities [ [ chronic hypertension, } \\
\text { COPD, pregestational diabetes, immunosuppression or } \\
\text { immunocompromised like HIV infected patients with }>350 \\
\text { CD4+ cells, organ transplantations, patients receiving } \\
\text { corticosteroids like prednisolone for more than } 2 \text { weeks and or } \\
\text { neutropenia] should be considered for stringent evaluation by } \\
\text { infectious disease specialist. } \\
\text { CURB severity scale with total score } 0 \text { [each item gives a score } \\
\text { of one point], where: } \\
\text { C: Confusion (acute in nature) } \\
\text { U: Urea levels more than } 19 \mathrm{mg} / \mathrm{dL} \\
\text { R: } \geq 30 \text { bpm } \\
\text { B: Systolic blood pressure } \leq 90 \mathrm{~mm} \mathrm{Hg} \text { or diastolic blood } \\
\text { pressure } \leq 60 \mathrm{~mm} \mathrm{Hg.}\end{array}$ & $\begin{array}{l}\text { - Need for invasive } \\
\text { mechanical ventilation } \\
\text { - Shock with the need for } \\
\text { vasopressors }\end{array}$ & $\begin{array}{ll}\text { - } & \text { Respiratory rate } \geq \mathrm{bmp} \\
\text { - } & \mathrm{PaO}_{2} / \text { Fio } \mathrm{r}_{2} \text { ratio }<250 \\
\text { - } & \text { Multilobular infiltrates } \\
\text { - } & \text { Confusion/disorientation } \\
\text { - } & \text { Uremia }[\mathrm{BUN}>20 \mathrm{mg} / \mathrm{dL}] \\
\text { - } & \text { Leukopenia }<4000 \mathrm{cells} / \mathrm{mm}^{3} \\
\text { - } & \text { Thrombocytopenia }<100000 \text { platelets/ } \\
& \mathrm{mm}^{3} \\
\text { - } & \text { Hypothermia/central }<36^{\circ} \mathrm{C} \\
\text { - } & \text { Hypotension in need of aggressive } \\
& \text { fluid resuscitation. }\end{array}$ \\
\hline
\end{tabular}

Table 2. Classification of COVID-19 case based on the severity of respiratory infection. Adapted from López M, Gonce A, Meler E, et al. Fetal Diagn Ther 2020;47:519-28. with permission [69].

$$
\text { Mild infection }
$$

Includes local symptoms like sore throat, cough, rhinorrhea or anosmia along with or without non-specific symptoms such as fever or myalgia and a CURB score of 0 .
Mild pneumonia [Chest x-ray confirmed pneumonia] with no serious signs, with basal $\mathrm{SO}_{2}>90 \%$, no need for vasopressor or ventilator support, with CURB score up to 1 . The patient should be admitted to the isolation ward [ideally in negative pressure set-up] along with constant monitoring of vital signs, supported with consultation with the specialists such as maternal-fetal, anesthesiologist and infectious diseases.

\section{Severe infection}

Severe pneumonia: If there is one or more than one organ failure, basal $\mathrm{SO}_{2}<90 \%$, respiratory rate $\geq 30 \mathrm{bpm}$, or there is need for vasopressors

Respiratory distress: Certain clinical findings such as [dyspnea, chest retraction] or with radiological evidence of bilateral infiltrates along with oxygen deficiency $\left[\mathrm{SO}_{2} /\right.$ fraction of inspired oxygen $\left(\mathrm{FiO}_{2}\right)$ ratio $\leq 315$ or $\mathrm{PaO}_{2} \mathrm{FiO}_{2}$ ratio $\leq 300$ Mild: $\mathrm{PaO}_{2} \mathrm{FiO}_{2}$ ratio 200-300

Moderate: $100-200$

Severe: $\leq 100$

Sepsis: The Sepsis-Related Organ Failure Assessment [SOFA] can be used to evaluate sepsis severity [consider if the score is >2] and also quick SOFA with two of the three following criteria: Glasgow $\leq 13$, systolic blood pressure $\leq 100 \mathrm{~mm} \mathrm{Hg}$, or respiratory rate $\geq 22 \mathrm{bpm}$.

Septic shock: Arterial hypotension that persists after resuscitation volume and that requires vasopressors to maintain a mean arterial pressure $\geq 65 \mathrm{mmHg}$ and lactate $\geq 2 \mathrm{mmol} / \mathrm{L}[18 \mathrm{mg} / \mathrm{dL}]$ in absence of hypovolemia. 
2020 [73] conducted a study on 44 COVID positive pregnant women and observed that these micronutrient levels were less compared to normal values. Hence, this deficiency may become vulnerable to COVID-19 infection. During a pandemic, micronutrient supplementation may be helpful during pregnancy.

\section{Remdesivir}

One of the cases reported about third-trimester pregnancy affected with COVID-19 required intensive care support along with Remdesivir treatment. However, elevated transaminases as a side effect were noticed but it was unclear whether transaminitis was due to Remdesivir or due to COVID infection [74].

\section{Lopinavir/ ritonavir (LPV/r)}

These drugs were considered safe during pregnancy based on earlier reports of LPV/r exposure to HIV pregnancy case; however, it has been reported that lopinavir has low placental transfer to fetus yet human teratogenicity was not found [75].

\section{Hydroxychloroquine}

Huybrechts et al. reports quantified the risk of congenital malformations/birth defects related to early pregnancy administered with hydroxychloroquine and its potential use as prophylaxis were notable [76].

\section{Heparin}

Thisis a heavy molecular anticoagulant chosen as safe during pregnancy and lactation since it does not cross the blood-brain barrier. in case of long-term effects, 2 main potential side effects need to be considered:osteoporosis and heparin-induced thrombocytopenia [77].

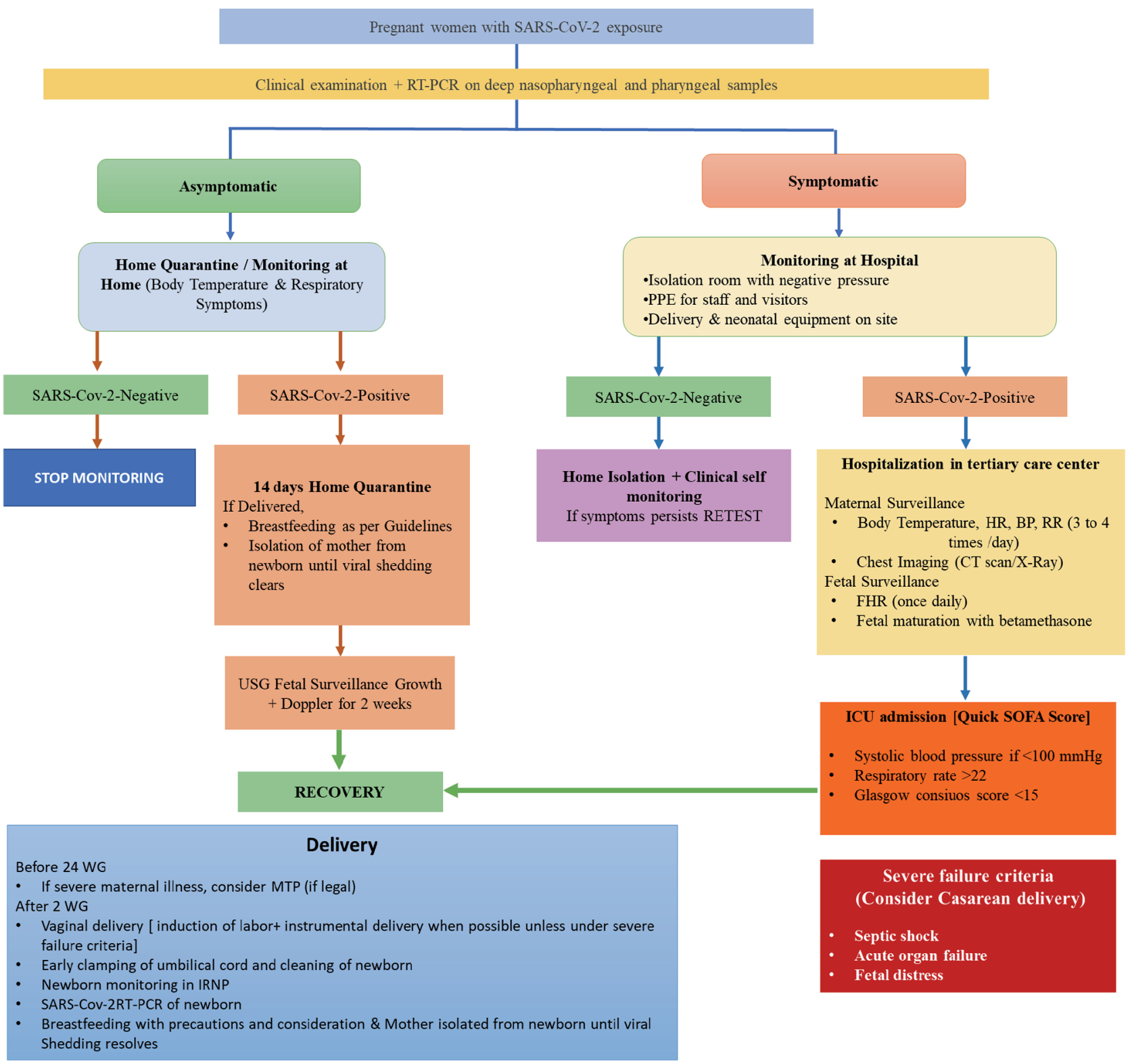

Figure 2. COVID-19 management during pregnancy. Adapted from Tripathi S, Gogia A, Kakar A. J Family Med Prim Care 2020;9:453640; with permission [99]. 


\section{Azithromycin}

Azithromycinworks by inhibiting the protein biosynthesis and bacteriostatic drug. Common side effects are nausea, vomiting, diarrhea, abdominal pain and, less frequently, a change in the electrical activity of the heart in particular by prolonging the QT interval. In fact, the addition of Azithromycin to the protocol with chloroquine it is not recommended as their combination may cause QT prolongation, with a greater risk of adverse cardiac effects. Azithromycin is classified as class B by FDA and commonly used in pregnancy and breastfeeding [78].

Recently, NIH U.S. National Library of Medicine has posted clinical trial (Phase 3) of Hydroxychloroquine and azithromycin treatment of pregnant COVID-19 patient with mild symptoms with expected outcome measures such as percentage of patients with a negative RT- PCR test result to COVID-19 nasopharyngeal swab at the $7^{\text {th }}$ day of treatment by hydroxychloroquine and azithromycin and measure maternal and neonatal outcomes [79].

\section{Ceftriaxone}

FDA approved this antibiotic under Category B safe for use in pregnancy and breastfeeding. This has side effects viz. diarrhea, pancreatitis, nausea or vomiting, etc. [80].

\section{Ivermectin}

Ivermectin is an anthelmintic agent. The antiviral function of ivermectin has recently been discovered. Ivermectin has been used

Table 3. Treatment approaches for COVID-19 with their limitations. Adapted from Favilli A, Mattei Gentili M, Raspa F, et al. J Matern Neonatal Med 2020;1-14; with permission [100].

\begin{tabular}{|c|c|c|c|c|c|}
\hline Drug class & Drug & Mechanism of Action & Dosage & $\begin{array}{l}\text { Limitations/ } \\
\text { Contradiction }\end{array}$ & References \\
\hline Antiviral & Remdesvir & $\begin{array}{l}\text { Inhibition of viral replication- Viral RNA- } \\
\text { dependent RNA polymerase blockage }\end{array}$ & $\begin{array}{l}5 \mathrm{mg} / \mathrm{ml} \text { vial } \\
\text { [reconstituted]. } \\
\text { Single i.v. } 200 \mathrm{mg} \\
\text { loading dose, } \\
\text { followed by } 100 \mathrm{mg} \\
\text { daily infusion } \\
\text { for } 9 \text { days }\end{array}$ & $\begin{array}{l}\text { Elevation of liver } \\
\text { enzymes (particularly } \\
\text { transaminase) [74] }\end{array}$ & $\begin{array}{l}\text { Mulangu et al., } 2019 . \\
{[85]}\end{array}$ \\
\hline Antiretrovi ral & $\begin{array}{l}\text { Lopinavir/ } \\
\text { Ritonavir }\end{array}$ & $\begin{array}{l}\text { Inhibition of viral replication and } \\
\text { release fro host cells: } \\
\text { Lopinavir inhibits viral enzyme 3- } \\
\text { chemotrypsin like protease } \\
\text { [3CLpro] } \\
\text { Ritonavir increases the half-life of } \\
\text { lopinavir by inhibiting cytochrome P450 } \\
3 \mathrm{~A}\end{array}$ & $\begin{array}{l}400 \mathrm{mg} / 100 \mathrm{mg} \\
\text { tablets, one tablet } \\
\text { bid. For up to } 14 \\
\text { days or } 200 \mathrm{mg} / 50 \\
\text { mg tablets, together } \\
\text { every } 12 \text { hours } \\
\text { with } \alpha \text {-IFN } 5 \\
\text { million IU in } 2 \mathrm{ml} \\
\text { of nebulized } \\
\text { physiologic } \\
\text { solution } \\
\text { regardless of } \\
\text { meals }\end{array}$ & $\begin{array}{l}\text { Low placental } \\
\text { transmission to fetus } \\
\text { No teratogenicity was } \\
\text { found [75] }\end{array}$ & $\begin{array}{l}\text { Chu et al., } 2020 \\
\text { [86] Koss et al., } 2014 \\
\text { [87] } \\
\text { Liang et al., } 2020 \text { [88] }\end{array}$ \\
\hline $\begin{array}{l}\text { Antiprotoz oal } \\
\text { Antirheum atic }\end{array}$ & Chloroquine & $\begin{array}{l}\text { Inhibition of host TNF- } \alpha \& \text { IL- } 6 \\
\text { production }\end{array}$ & $\begin{array}{l}500 \text { mg or } 250 \\
\text { mg tablets: } 500 \mathrm{mg} \\
\text { oral every } 12 \text { to } 24 \\
\text { hr for } 5 \text { to } \\
10 \text { days; or } 1 \mathrm{gm} \\
\text { oral for the first } \\
\text { day of the } \\
\text { treatment and then } \\
500 \mathrm{mg} \\
\text { daily for } 4 \text { to } 7 \\
\text { days depending } \\
\text { up on clinical } \\
\text { response. }\end{array}$ & $\begin{array}{l}\text { Risk of congenital } \\
\text { anomalies [76] }\end{array}$ & $\begin{array}{l}\text { Sanders et al., } 2020 . \\
\text { [89] } \\
\text { Berghella, } 2020 \\
{[48]} \\
\text { Klumpp, } 1965 \\
\text { [90] }\end{array}$ \\
\hline $\begin{array}{l}\text { Antimalari al } \\
\text { Antiprotoz oal } \\
\text { Antirheum atic }\end{array}$ & $\begin{array}{l}\text { Hydroxychlo } \\
\text { roquine }\end{array}$ & $\begin{array}{l}\text { Inhibition of viral host cell penetration, } \\
\text { viral replication, and mitigation of host } \\
\text { inflammatory response } \\
\text { Inhibition of terminal ACE-2 } \\
\text { glicosilation } \\
\text { Increases endosomal pH. }\end{array}$ & $\begin{array}{l}200 \text { mg tablets: } \\
400 \text { mg oral } \\
\text { every } 12 \text { hours for } \\
\text { one day followed by } \\
200 \\
\text { mg every } 12 \text { hours } \\
\text { for } 4 \text { days or } 400 \mathrm{mg} \\
\text { daily for } 5 \text { days or } \\
200 \\
\text { mg every } 8 \text { hours } \\
\text { for } 10 \text { days. }\end{array}$ & $\begin{array}{l}\text { Risk of congenital } \\
\text { anomalies [76] }\end{array}$ & $\begin{array}{l}\text { Sanders et al., } 2020 . \\
\text { [89] } \\
\text { Berghella, } 2020 \\
\text { [48] } \\
\text { Klumpp, } 1965 \\
\text { [90] }\end{array}$ \\
\hline Anticoagul ant & Heparin & $\begin{array}{l}\text { Inhibition of viral host cell penetration } \\
\text { Prevention of endovascular } \\
\text { thrombosis } \\
\text { Inhibition of Factor Xa }\end{array}$ & $\begin{array}{l}4000 \text { IU S.C. } \\
\text { daily [also during } \\
\text { post-partum if still } \\
\text { positive] }\end{array}$ & $\begin{array}{l}\text { Osteoporosis and } \\
\text { heparin- induced } \\
\text { thrombocytopeni a [76] }\end{array}$ & $\begin{array}{l}\text { Berghella, } 2020 \\
\text { [48] } \\
\text { Di Renzo et al., } 2020 \\
{[94]}\end{array}$ \\
\hline
\end{tabular}


Table 3. Continued from previous page.

\begin{tabular}{|c|c|c|c|c|c|}
\hline Drug class & Drug & Mechanism of Action & Dosage & $\begin{array}{l}\text { Limitations/ } \\
\text { Contradiction }\end{array}$ & References \\
\hline Corticoster oids & $\begin{array}{l}\text { Betamethaso ne } \\
\text { and } \\
\text { Prednisolone }\end{array}$ & $\begin{array}{l}\text { Mitigation of host inflammatory } \\
\text { response. } \\
\text { Inhibition of host IL- 1, IL-2, IL-6, IL- } \\
12 \text {, INF-y \& TNF- } \alpha \\
\text { production }\end{array}$ & $\begin{array}{l}12 \text { mg i.m. two } \\
\text { injection } 24 \mathrm{hr} \\
\text { apart as } \\
\text { prophylaxis for } \\
\text { fetal lung } \\
\text { maturation. }\end{array}$ & $\begin{array}{l}\text { Classified as C/D } \\
\text { approved drugs by } \\
\text { FDA }\end{array}$ & $\begin{array}{l}\text { Poon et al, } 2020 \text { [92] } \\
\text { Kakoulidis et al., } 2020 \\
\text { [93] }\end{array}$ \\
\hline Antibiotic & Azithromyci n & $\begin{array}{l}\text { Inhibition of viral host cell penetration. } \\
\text { Inhibition of terminal ACE-2 } \\
\text { glicosilation. } \\
\text { Inhibits the } 50 \mathrm{~S} \\
\text { subunit of bacterial ribosome }\end{array}$ & $\begin{array}{l}500 \mathrm{mg} / \text { day for } \\
3-5 \text { days depending } \\
\text { on clinical } \\
\text { response. }\end{array}$ & $\begin{array}{l}\text { Class B drug } \\
\text { Contradiction: } \\
\text { Combination with } \\
\text { Chloroquine causes QT } \\
\text { prolongation with } \\
\text { greater risk } \\
\text { of Cardiac } \\
\text { effects [78] }\end{array}$ & [94] \\
\hline \multirow[t]{2}{*}{ Antibiotic } & Ceftriaxone & $\begin{array}{l}\text { Produces bactericidal effects by } \\
\text { interfering with the synthesis of } \\
\text { peptidoglycan layer }\end{array}$ & $\begin{array}{l}\text { lgm i.m. or 1-2 gm } \\
\text { i.v. daily depending } \\
\text { up on clinical } \\
\text { response }\end{array}$ & $\begin{array}{ll}\text { Class B } & \text { drug } \\
\text { approved by } & \text { FDA } \\
\text { [80] } & \end{array}$ & $\begin{array}{l}\text { https://www.acce } \\
\text { ssdata.fda.gov/dr } \\
\text { ugsatfda_docs/nd } \\
\text { a/2005/050796s0 } \\
\text { 00_PRNTLBL.pdf [80] }\end{array}$ \\
\hline & $\begin{array}{l}\text { Convalescent } \\
\text { plasma }\end{array}$ & $\begin{array}{l}\text { Direct neutralization of virus } \\
\text { Mitigation of host inflammatory } \\
\text { response \&immunoodulation of a } \\
\text { hypercoagulable state } \\
\text { Anti-idiotypic antibodies blocking } \\
\text { autoreactive antibodies. }\end{array}$ & $\begin{array}{l}\text { Lack of data on } \\
\text { pregnancy }\end{array}$ & $\begin{array}{l}\text { Lack of data on } \\
\text { pregnancy }\end{array}$ & $\begin{array}{l}\text { Van Griensven et al., } \\
2016 \text { [95] }\end{array}$ \\
\hline $\begin{array}{l}\text { Monoclona I } \\
\text { Antibody }\end{array}$ & Tocilizumab & $\begin{array}{l}\text { Mitigation of host inflammatory } \\
\text { response } \\
\text { Blocks the membrane bound IL-6 } \\
\text { receptor }\end{array}$ & $\begin{array}{l}400 \mathrm{mg} \text { IV for } 1- \\
2 \text { doses. Second } \\
\text { dose after } 8-12 \mathrm{~h} \text { if } \\
\text { required (infuse in } \\
60 \mathrm{~min} \text { ) }\end{array}$ & Not assigned by FDA & $\begin{array}{l}\text { Weber-Schoendorfer } \\
\text { et al., } 2016 \text { [96] }\end{array}$ \\
\hline $\begin{array}{l}\text { Immunom } \\
\text { odulator }\end{array}$ & Interferon -I & $\begin{array}{l}\text { Inhibition of viral replication } \\
\text { Mitigation of host inflammatory } \\
\text { response } \\
\text { Hinders the cellular metabolism } \\
\text { Inhibits host Il-1b and TNF- } \alpha \\
\text { production. }\end{array}$ & $\begin{array}{l}\text { Limited data } \\
\text { available } \\
\text { (variable dose) }\end{array}$ & $\begin{array}{l}\text { Limited data } \\
\text { available }\end{array}$ & $\begin{array}{l}\text { Yazdani et al., } 2012 \\
{[97]} \\
\text { Romero et al., } 2015 \\
{[98]}\end{array}$ \\
\hline
\end{tabular}

in current clinical trials at doses of 200 to $1200 \mathrm{mcg} / \mathrm{kg}$ for $3-7$ days, showing a positive response to reduce viral load and symptomatically relief.

However, Ivermectin was shown to be teratogenic in preclinical studies using pregnant experimental animals. However, there were no appropriate and well-controlled trials are available for pregnant women. Since protection in pregnancy has not been developed, Ivermectin should not be used during pregnancy. The data also suggests that the drug is excreted at low concentrations in human milk. Treatment of lactating mothers should be undertaken only if the possibility of delayed mother-to-mother treatment exceeds the potential risk for neonates [81].

\section{COVID-19 vaccination: is it prioritized to pregnant women?}

India started the COVID-19 vaccination drive on $16^{\text {th }}$ January 2021. To start with, workers would be vaccinated. Till now, DCGI approved 'Covishield' and 'Covaxin' as emergency use in India. However, for instance as per WHO reports no relevant/insufficient data to recommend the vaccination of pregnant women. Although several vaccine efficacy and safety studies were conducted with pregnant and lactating women during the H1N1 pandemic, the COVID-19 vaccine trials have excluded these groups, and therefore, critical perinatal safety information remains largely unknown [82]. In one the survey it is claimed that acceptance of COVID-19 vaccine among pregnant women and mothers of children younger than 18 years old were assessed through an online survey which reports that generally vaccine acceptance was highest in India compared to other countries. The acceptance depends on compliance with guidelines set by government and varies globally. Campaigns are essential to establish the trust of vaccination among the children and pregnant women [83].

\section{Conclusions}

December 2019 has been remembered as a pandemic month due to the spread of COVID-19 globally. Given the novelty of COVID-19, data on the effect of COVID-19 on the pregnancy and the newborn are so far limited to few small case reports and 
case series; however, early reports and lessons from SARS, MERS, and other infections give an insight that pregnant women could have severe clinical course. The lack of early diagnosis, specific treatment conditions lead clinicians to choose earlier drugs having their efficacy against similar viruses or in-vitro tests due to emerging situations. The vulnerable group especially COVID-19 infected pregnant women and their complications have been ignored during a pandemic scenario. The exclusion of pregnant women in a clinical trial is well known despite in search of treatment of COVID-19 for non-vulnerable groups and criteria are not justified as many of the treatments are used with low safety measures. Inclusion may be needed to identify better treatment options for this population [84]. Due to a paucity of inconsistent data regarding the impact of COVID-19 on pregnant women, caution should be undertaken to further investigate and monitor possible effects in pregnant women. A current overview may be useful for health care providers for practical approach and limitation of drugs used in the current management and considers the choice of drugs with their special attention given to adverse effects to improvise maternal health, pregnancy, and birth outcomes. The basis of treatment for all pregnant women with COVID-19 is the standard intervention to treat any significant respiratory infection and should be applied vigorously in a teambased care model.

\section{References}

1. Phoswa WN, Khaliq OP. Is pregnancy a risk factor of COVID19? Eur J Obstet Gynecol Reprod Biol 2020;252:605-9.

2. World Health Organization. COVID-19 Dashboard. 2020. Accessed 25 July 2020. Available from: https://covid19.who.int/

3. Dennison Himmelfarb CR, Baptiste D. Coronavirus Disease (COVID-19): Implications for cardiovascular and socially atrisk populations. J Cardiovasc Nurs 2020;35:318-21.

4. Government of India. AarogyaSetu mobile application. Available from: https://aarogyasetu.gov.in/

5. Government of India, Ministry of Health and Family Welfare. COVID-19 Statewise Status. Accessed 3 Novermber 2020. Available from: https://www.mohfw.gov.in/

6. Rasmussen SA, Smulian JC, Lednicky JA, et al. Coronavirus Disease 2019 (COVID-19) and pregnancy: what obstetricians need to know. Am J Obstet Gynecol 2020;222:415-26.

7. Guan W-J, Ni Z-Y, Hu Y, et al. Clinical characteristics of coronavirus disease 2019 in China. N Engl J Med 2020;382:1708-20.

8. Huang C, Wang Y, Li X, et al. Clinical features of patients infected with 2019 novel coronavirus in Wuhan, China. Lancet 2020;395:497-506.

9. Rothan HA, Byrareddy SN. The epidemiology and pathogenesis of coronavirus disease (COVID-19) outbreak. J Autoimmun 2020;109:102433.

10. Ryan GA, Purandare NC, McAuliffe FM, et al. Clinical update on COVID-19 in pregnancy: A review article. J Obstet Gynaecol Res 2020;46:1235-45.

11. Dashraath P, Wong JLJ, Lim MXK, et al. Coronavirus disease 2019 (COVID-19) pandemic and pregnancy. Am J Obstet Gynecol 2020;9378:303434.

12. Yu N, Li W, Kang Q et al. Clinical features and obstetric and neonatal outcomes of pregnant patients with COVID19 in Wuhan, China: A retrospective, single centre, descriptive study. Lancet Infect Dis 2020;20:559-64.

13. Zhao W, Zhang J, Meadows ME, et al. A systematic approach is needed to contain COVID-19 globally. Sci Bull 2020;65:876-8.

14. Juusela A, Nazir M, Gimovsky M. Two cases of coronavirus 2019-related cardiomyopathy in pregnancy. Am J Obstet Gynecol MFM 2020;2:100113.

15. Ren L-L, Wang Y-M, Wu Z-Q, et al. Identification of a novel coronavirus causing severe pneumonia in human: a descriptive study. Chin Med J 2020;133:1015-24.

16. Wang W, Tang J, Wei F. Updated understanding of the outbreak of 2019 novel coronavirus $(2019 \mathrm{nCoV})$ in Wuhan, China. J Med Virol 2020;92:441-7.

17. Carlos WG, Dela Cruz CS, Cao B, et al. Novel Wuhan (2019nCoV) coronavirus Am J Respir Crit Care Med 2020;201:7-8.

18. Pal M, Berhanu G, Desalegn C, Kandi V. Severe acute respiratory syndrome coronavirus- 2 (SARS-CoV-2): An Update. Cureus. 2020;12;e7423.

19. Cheng B, Jiang T, Zhang L, et al. Clinical characteristics of pregnant women with coronavirus disease 2019 in Wuhan, China. Open Forum Infect Dis 2020;7:ofaa294.

20. Chen Y, Liu Q, Guo D. Emerging coronaviruses: genome structure, replication, and pathogenesis $\mathrm{J}$ Med Virol 2020;92:418-23.

21. Wan Y, Shang J, Graham R, et al. Receptor recognition by the novel coronavirus from Wuhan: an analysis based on decadelong structural studies of SARS coronavirus. J Virol 2020;94:e00127-20.

22. Shereen MA, Khan S, Kazmi A, et al. COVID-19 infection: origin, transmission, and characteristics of human coronaviruses J Adv Res 2020;24:91-8.

23. Koyasu S, Moro K. Role of innate lymphocytes in infection and inflammation. Front Immunol 2012;3:101.

24. Kühnert M, Strohmeier R, Stegmüller M, Halberstadt E. Changes in lymphocyte subsets during normal pregnancy. Eur J Obstet Gynecol Reprod Biol 1998;76:147-51.

25. Hanna N, Hanna M, Sharma S. Is pregnancy an immunological contributor to severe or controlled COVID-19 disease? Am J Reprod Immunol 2020;84:e13317.

26. Thachil J, Tang N, Gando S. ISTH interim guidance on recognition and management of coagulopathy in COVID-19. J Thromb Haemost 2020;18:1023-6.

27. Zhou F, Yu T, Du R, et al. Clinical course and risk factors for mortality of adult inpatients with COVID-19 in Wuhan, China: a retrospective cohort study Lancet 2020;395:1054-62.

28. Zhou Y, Fu B, Zheng X, et al. Pathogenic T cells and inflammatory monocytes incite inflammatory storm in severe COVID-19 patients. Natl Sci Rev 2020;7:998-1002.

29. Ruan Q, Yang K, Wang W, et al. Clinical predictors of mortality due to COVID-19 based on an analysis of data of 150 patients from Wuhan, China. Intensive Care Med 2020;46:846- 8.

30. Bandyopadhyay D, Akhtar T, Hajra A, et al. COVID-19 pandemic: Cardiovascular complications and future implications. Am J Cardiovasc Drugs 2020;20:311-24.

31. Alberca RW, Pereira NZ, Oliveira LMDS, et al. Pregnancy, viral infection, and COVID-19. Front Immunol 2020;11:1672.

32. Pringle KG, Tadros MA, Callister RJ, Lumbers ER. The expression and localization of the human placental prorenin/renin-angiotensin system throughout pregnancy: roles in trophoblast invasion and angiogenesis? Placenta 2011;32:956-62.

33. Levy A, Yagil Y, Bursztyn M, et al. ACE2 expression and activity are enhanced during pregnancy. Am J Physiol Regul Integr Comp Physiol 2008;295:R1953-61.

34. Neves LA, Stovall K, Joyner J, et al. ACE2 and ANG-(1-7) in 
the rat uterus during early and late gestation. Am J Physiol Regul Integr Comp Physiol 2008;294:R151-61.

35. Hoffmann M, Kleine-Weber H, Schroeder S, et al. SARS-CoV2 cell entry depends on ACE2 and TMPRSS2 and is blocked by a clinically proven protease inhibitor. Cell 2020;181:271-80.

36. Zmora P, Moldenhauer AS, Hofmann-Winkler H, Pöhlmann S. TMPRSS2 isoform 1 activates respiratory viruses and is expressed in viral target cells. PLoS One 2015;10:e0138380.

37. Vaarala MH, Porvari KS, Kellokumpu S, et al. Expression of transmembrane serine protease TMPRSS2 in mouse and human tissues. J Pathol 2001;193:134-40.

38. Lin B, Ferguson C, White JT, et al. Prostate-localized and androgen-regulated expression of the membrane-bound serine protease TMPRSS2. Cancer Res 1999;59:4180-4.

39. Li M, Chen L, Zhang J, et al. The SARS-CoV-2 receptor ACE2 expression of maternal- fetal interface and fetal organs by single-cell transcriptome study. PLoS One 2020;15:e0230295.

40. Pique-Regi R, Romero R, Tarca AL, et al. Does the human placenta express the canonical cell entry mediators for SARSCoV-2? Elife 2020;9:e58716.

41. Wang K, Chen W, Zhou Y-S, et al. 2020. SARS-CoV-2 invades host cells via a novel route: CD147-spike protein. Accessed on: March 23, 2021. bioRxiv 2020.

42. Brosnihan KB, Neves LAA, Anton L, et al. Enhanced expression of Ang-(1-7) during pregnancy. Braz J Med Biol Re. 2004;37:1255-62.

43. West CA, Sasser JM, Baylis C. The enigma of continual plasma volume expansion in pregnancy: Critical role of the reninangiotensin-aldosterone system. Am J Physiol Renal Physiol 2016;311:F1125-34.

44. Emanuele N, Ren J, Lapaglia N, et al. Angiotensin-(1-7) in normal and preeclamptic pregnancy. Endocrine 2002;18:239-45.

45. Garovic VD, White WM, Vaughan L, et al. Incidence and longterm outcomes of hypertensive disorders of pregnancy. J Am Coll Cardiol 2020;75:2323-34.

46. Glowacka I, Bertram S, Herzog P, et al. Differential downregulation of ACE2 by the spike proteins of severe acute respiratory syndrome coronavirus and human coronavirus NL63. J Virol 2010;84:1198-205.

47. Ferrario CM, Trask AJ, Jessup JA. Advances in biochemical and functional roles of angiotensin-converting enzyme 2 and angiotensin-(1-7) in regulation of cardiovascular function. Am J Physiol Heart Circ Physiol 2005;289:H2281-90.

48. Berghella V, Hughes B, Coronavirus disease 2019 (COVID19): Prenatal issues and care. Available from: https://www. uptodate.com/contents/covid-19-pregnancy-issues-and- antenatal-care

49. Kotlyar AM, Grechukhina O, Chen A, et al. Vertical transmission of coronavirus disease 2019: a systematic review and meta-analysis. Am J Obstet Gynecol 2021;224:35-53.

50. Walker KF, O'Donoghue K, Grace N, et al. Maternal transmission of SARS-COV-2 to the neonate, and possible routes for such transmission: a systematic review and critical analysis. BJOG 2020;127:1324-36.

51. Flaherman VJ, Afshar Y, Boscardin J, et al. Infant outcomes following maternal infection with SARS-CoV-2: First report from the PRIORITY Study. Clin Infect Dis 2020; ciaa1411. Online Ahead of print.

52. Shah PS, Diambomba Y, Acharya G, et al. Classification system and case definition for SARS-CoV-2 infection in pregnant women, fetuses, and neonates. Acta Obstet Gynecol Scand 2020;99:565.

53. Dashraath P, Wong JLJ, Lim MXK, et al. Coronavirus disease
2019 (COVID-19) pandemic and pregnancy. Am J Obstet Gynecol 2020;78:303434.

54. Blanco-Melo D, Nilsson-Payant BE, Liu WC, et al. Imbalanced host response to SARS- CoV-2 drives development of COVID-19. Cell 2020;181:1036-45.

55. Ghadhanfar E, Alsalem A, Al-Kandari S, et al. The role of ACE2, angiotensin-(1-7) and Mas1 receptor axis in glucocorticoid-induced intrauterine growth restriction. Reprod Biol Endocrinol 2017;15:97.

56. Mahmoud H, Taha MS, Askoura A, et al. Can chest CT improve sensitivity of COVID-19 diagnosis in comparison to RT-PCR? A meta-analysis study. Egypt J Otolaryngol 2020;36:49.

57. Bai HX, Hsieh B, Xiong Z, et al. Performance of radiologists in differentiating COVID-19 from viral pneumonia on chest CT. Radiology 2020;296:E46-54.

58. Ai T, Yang Z, Hou H, et al. Correlation of chest CT and RTPCR testing in coronavirus disease 2019 (COVID-19) in China: a report of 1014 cases. Radiology 2020;296:E32-40.

59. Fang Y, Zhang H, Xie J, et al. Sensitivity of Chest CT for COVID-19: Comparison to RT- PCR. Radiology 2020;296: 115-7.

60. Kim H., Hong H., Yoon S. H. Diagnostic performance of CT and reverse transcriptase- polymerase chain reaction for coronavirus disease 2019: a meta-analysis. Radiology 2020;296:E145-55.

61. Corman MV, Landt O, Kaiser M, et al. Detection of 2019 novel coronavirus (2019-nCoV) by real-time RT-PCR. EuroSurveill 2020;25:2000045.

62. Liang H, Acharya G. Novel corona virus disease (COVID-19) in pregnancy: What clinical recommendations to follow? Acta Obstet Gynecol Scand 2020;99:439-42.

63. Allotey J, Stallings E, Bonet M, et al. Clinical manifestations, risk factors, and maternal and perinatal outcomes of coronavirus disease 2019 in pregnancy: living systematic review and meta-analysis. BMJ 2020;370:3320.

64. Vega M, Hughes F, Bernstein PS, et al. From the trenches: inpatient management of coronavirus disease 2019 in pregnancy. Am J Obstet Gynecol MFM 2020;2:00154.

65. Futterman I, Toaff M, Navi L, Clare CA. COVID-19 and HELLP: Overlapping clinical pictures in two gravid patients. AJP Rep 2020;10:e179-82.

66. Mendoza M, Garcia-Ruiz I, Maiz N, et al. Pre-eclampsia-like syndrome induced by severe COVID-19: a prospective observational study. BJOG 2020; 127:1374.

67. Zitiello A, Grant GE, Ben Ali N, Feki A. Thrombocytopaenia in pregnancy: the importance of differential diagnosis during the COVID-19 pandemic. J Matern Fetal Neonatal Med 2020. Online ahead of print.

68. Mahajan NN, Pednekar R, Patil SR, et al. Preparedness, administrative challenges for establishing obstetric services, and experience of delivering over 400 women at a tertiary care COVID-19 hospital in India. Int $\mathrm{J}$ Gynecol Obstet 2020;151:188-96.

69. López M, Gonce A, Meler E, et al. Coronavirus disease 2019 in pregnancy: A clinical management protocol and considerations for practice. Fetal Diagn Ther 2020;47:519-28.

70. Ashokka B, Loh MH, Tan CH. Care of the pregnant woman with COVID-19 in Labor and Delivery: anesthesia, emergency cesarean delivery, differential diagnosis in the acutely ill parturient, care of the newborn, and protection of the healthcare personnel. Am J Obstet Gynecol 2020;223:66-74.

71. ClinicalTrials.gov [Internet]. Bethesda (MD): National Library 
of Medicine (US). 2020 May 21 - Identifier NCT04397757. COVID-19 Convalescent plasma for the treatment of hospitalized patients with pneumonia caused by SARS-CoV-2. Available from: https://clinicaltrials.gov/ct2/show/NCT04397757

72. ClinicalTrials.gov [Internet]. Bethesda (MD): National Library of Medicine (US). 2020 May 14 - Identifier NCT04388527. COVID-19 convalescent plasma for mechanically ventilated population. Available from: https://clinicaltrials.gov/ct2/show/ NCT04388527

73. Yalcin Bahat P, Aldikactioglu Talmac M, Bestel A, et al. Micronutrients in COVID-19 positive pregnancies. Cureus 2020;12:10-4.

74. Maldarelli GA, Savage M, Mazur S, et al. Remdesivir treatment for severe COVID-19 in third-trimester pregnancy: Case report and management discussion. Open Forum Infect Dis 2020;7:1-4.

75. Dashraath P, Wong JLJ, Lim MXK, et al. Coronavirus disease 2019 (COVID-19) pandemic and pregnancy. Am J Obstet Gynecol 2020;222:521-31.

76. Huybrechts KF, Bateman BT, Zhu Y, et al. Hydroxychloroquine early in pregnancy and risk of birth defects. Am J Obstet Gynecol 2020;224:290.

77. Ariel M, Gideon K. Low-molecular-weight heparins during pregnancy. Can Fam Physician 2005;51:199-201.

78. Kim AY, Gandhi RT. COVID-19: Management in hospitalized adults. Accessed on 2020 May 30. Available from: https://www.uptodate.com/contents/coronavirus-disease2019- COVID-19-management-in-hospitalized-adults

79. ClinicalTrials.gov [Internet]. Bethesda (MD): National Library of Medicine (US). 2020 May 14 - Identifier NCT04365231. Hydroxychloroquine azithromycin COVID-19 pregnancy trial (HASCOPT). Available from: https://clinicaltrials.gov/ct2/ show/NCT04365231

80. US Food and Drug Administration [Internet]. Ceftriaxone Drug Approval Package. Accessed on: 2020 May 20. Available from: https://www.accessdata.fda.gov/drugsatfda_docs/nda/2005/050 796s000_PRNTLBL.pdf

81. Kesmen M, Anlaş C, Bakirel T, Güler EM. COVID-19: Ivermectin; Molecular mechanisms, limitations, suggestions. Bezmialem Sci 2020;8:94-8.

82. Stafford IA, Parchem JG, Sibai BM. The coronavirus disease 2019 vaccine in pregnancy: risks, benefits, and recommendations. Am J Obstet Gynecol 2021;224:484-95.

83. Skjefte M, Ngirbabul M, Akeju O, et al. COVID-19 vaccine acceptance among pregnant women and mothers of young children: results of a survey in 16 countries. Eur J Epidemiol 2021;36:197-211.

84. Taylor MM, Kobeissi L, Kim C, et al. Inclusion of pregnant women in COVID-19 treatment trials: a review and global call to action. Lancet Glob Health 2020;9:e366-71.

85. Mulangu S, Dodd LE, Davey RT, Jr, et al. A randomized, con- trolled trial of Ebola Virus disease therapeutics. N Engl J Med 2019;381:2293-303.

86. Chu CM, Cheng VCC, Hung NF, et al. Role of lopinavir/ritonavir in the treatment of SARS: initial virological and clinical findings. Thorax 2004;59:252-6.

87. Koss CA, Natureeba P, Plenty A, et al. Risk factors for preterm birth among HIV-infected pregnantUgandan women randomized to lopinavir/ritonaviror efavirenz-based antiretroviral therapy. J Acquir Immune Defic Syndr 2014;67:128-35.

88. Liang H, Acharya G. Novel corona virus disease (COVID-19) in pregnancy: what clinical recommendations to follow? Acta Obstet Gynecol Scand 2020;99:439-42.

89. Sanders JM, Monogue ML, Jodlowski TZ, et al. Pharmacologic treatments for coronavirus disease 2019 (COVID-19). A Review. JAMA 2020;323:1824-36.

90. Klumpp TG. Safety of chloroquine in pregnancy. JAMA 1965;191:765.

91. Di Renzo GC, Giardina I. COVID-19 in pregnancy: consider thromboembolic disorders and thromboprophylaxis. Am J Obstet Gynecol 2020;20:30465-8.

92. Poon LC, Yang H, Kapur A, et al. Global interim guidance on coronavirus disease 2019 (COVID-19) during pregnancy and puerperium from FIGO and allied partners: information for healthcare professionals. Int J Gynaecol Obstet 2020;149: 273-86.

93. Kakoulidis I, Ilias I, Koukkou E. SARS-CoV-2 infection and glucose homeostasis in pregnancy. What about antenatal corticosteroids? Diabetes Metab Syndr 2020;14:519-20.

94. US Food and Drug Administration [Internet]. Azithromycin Drug Approval Package. Accessed on: 2020 May 20. Available from: https://www.accessdata.fda.gov/drugsatfda_docs/nda/ 2002/50-710S011_Zithromax_Prntlbl.pdf

95. van Griensven J, Edwards T, de Lamballerie X, et al. Efficacy of convalescent plasma in relation to dose of Ebola Virus antibodiesefficacy of convalescent plasma in relation to dose of Ebola Virus antibodies. New Eng J Med 2016;375:2307-9.

96. Weber-Schoendorfer C, Schaefer C. Pregnancy outcome after tocilizumab therapy in early pregnancy-a case series from the German Embryotox Pharmacovigilance Center. Reprod Toxicol 2016;60:29-32.

97. Yazdani BP, Matok I, Garcia BF, et al. A systematic review of the fetal safety of interferon alpha. Reprod Toxicol 2012;33:265-8.

98. Romero RS, Lunzmann C, Bugge JP. Pregnancy outcomes in patients exposed to interferon beta-1b. J Neurol Neurosurg Psychiatry 2015;86:587-9.

99. Tripathi S, Gogia A, Kakar A. COVID-19 in pregnancy: A review. J Family Med Prim Care 2020;9:4536-40.

100. Favilli A, Mattei Gentili M, Raspa F, et al. Effectiveness and safety of available treatments for COVID-19 during pregnancy: a critical review. J Matern Neonatal Med 2020;1-14. 